\title{
Everyday functioning in a community-based volunteer population: Differences between participant- and study partner- report
}

\author{
M. Verrijp ${ }^{1 \dagger}$, M.A. Dubbelman ${ }^{1 \dagger}$, L.N.C. Visser ${ }^{1,2}$, R.J. Jutten ${ }^{1}$, E.W. Nijhuis ${ }^{1}$, M.D. Zwan ${ }^{1}$, H.P.J. \\ van Hout ${ }^{3}$, P. Scheltens ${ }^{1}$, W.M. van der Flier ${ }^{1,4}$, S.A.M. Sikkes ${ }^{1,5}$
}

\begin{abstract}
$\dagger$ These authors have contributed equally to this work and share first authorship.
${ }^{1}$ Alzheimer Center Amsterdam, Department of Neurology, Amsterdam Neuroscience, Vrije Universiteit Amsterdam, Amsterdam UMC, Amsterdam, The Netherlands

2 Division of Clinical Geriatrics, Center for Alzheimer Research, Department of Neurobiology, Care Sciences and Society, Karolinska Institutet, Stockholm, Sweden

${ }^{3}$ Department of General Practice and Medicine for Older Persons, Amsterdam Public Health Research Institute, Amsterdam University Medical Center,Vrije Universiteit, Amsterdam, The Netherlands

${ }^{4}$ Department of Epidemiology and Biostatistics, Amsterdam UMC, Amsterdam, The Netherlands ${ }^{5}$ Faculty of Behavioural and Movement Sciences, Clinical Developmental Psychology \& Clinical Neuropsychology, Vrije Universiteit Amsterdam, Amsterdam, The Netherlands
\end{abstract}

Keywords: instrumental activities of daily living; self-report; aging; study partner; preclinical; awareness; Alzheimer's disease; dementia 
medRxiv preprint doi: https://doi.org/10.1101/2021.11.01.21265650; this version posted November 2, 2021. The copyright holder for this preprint (which was not certified by peer review) is the author/funder, who has granted medRxiv a license to display the preprint in It is made available under a CC-BY-NC-ND 4.0 International license .

RUNNING TITLE: Everyday functioning: Differences between dyads

\begin{abstract}
INTRODUCTION: Impaired awareness in dementia due to Alzheimer's disease and related disorders, made study partner-report the preferred method of measuring interference in 'instrumental activities of daily living' (IADL). However, with a shifting focus towards earlier disease stages and prevention, the question arises whether self-report might be equally or even more appropriate. This study aims to investigate how participant and study partner report IADL perform in a community-based volunteer population without dementia, and which factors relate to differences between participant and study partner report.
\end{abstract}

METHODS: Participants ( $\mathrm{N}=3288 ; 18-97$ years, $70.4 \%$ females) and their study partners $(\mathrm{N}=1213$; 18-88 years, $45.8 \%$ females) were recruited from the Dutch brain research registry. IADL was measured using the Amsterdam IADL Questionnaire. Concordance between participant and study partner-reported IADL difficulties was examined using intraclass correlation coefficient (ICC). Multinomial logistic regressions were used to investigate which demographic, cognitive and psychosocial factors related to participant and study partner differences, by looking at the overand underreport of IADL difficulties by the participant, relative to their study partner.

RESULTS: The vast majority of A-IADL-Q scores represented no difficulties for both participants (87.9\%) and study partners (89.4\%). Concordance between participants and study partners was moderate $(\mathrm{ICC}=.55,95 \% \mathrm{Cl}=[.51, .59]), 24.5 \%(\mathrm{~N}=297)$ of participants overreported their IADL difficulties compared to study partners, and $17.8 \%(\mathrm{~N}=216)$ underreported difficulties. The presence of depressive symptoms (odds ratio $(\mathrm{OR})=1.31,95 \% \mathrm{Cl}=[1.12,1.54]$ ), as well as memory complaints $(\mathrm{OR}=2.45,95 \% \mathrm{Cl}=[1.80,3.34])$, increased the odds of participants overreporting their IADL difficulties. Higher IADL ratings decreased the odds of participant underreport $(\mathrm{OR}=0.71$, $95 \% \mathrm{Cl}=[0.67,0.74])$.

CONCLUSION: In this sample of community-based volunteers, the majority of participants and study partners reported no major IADL difficulties. Differences between participant and study partner were, however, quite prevalent, with subjective factors indicative of increased report of IADL difficulties by the participant in particular. These findings suggest that self- and study partner-report 
medRxiv preprint doi: https://doi.org/10.1101/2021.11.01.21265650; this version posted November 2, 2021. The copyright holder for this preprint (which was not certified by peer review) is the author/funder, who has granted medRxiv a license to display the preprint in It is made available under a CC-BY-NC-ND 4.0 International license.

RUNNING TITLE: Everyday functioning: Differences between dyads

measures may not be interchangeable, and that the level of awareness needs to be taken into account, even in cognitively healthy individuals. 
medRxiv preprint doi: https://doi.org/10.1101/2021.11.01.21265650; this version posted November 2, 2021. The copyright holder for this preprint (which was not certified by peer review) is the author/funder, who has granted medRxiv a license to display the preprint in It is made available under a CC-BY-NC-ND 4.0 International license .

RUNNING TITLE: Everyday functioning: Differences between dyads

\section{Introduction}

Decline in cognitively complex 'instrumental activities of daily living' (IADL) is among the first observable indicators of cognitive problems in everyday life, and is considered inherently clinically meaningful. Previous studies have shown that study partners report a decline in IADL in preclinical Alzheimer's disease (AD), even before cognitive problems can be detected by standard cognitive testing (1-3). IADL instruments are considered an important outcome in clinical trials and intervention studies, even more so as the field shifts towards preclinical phases of AD and related disorders (4).

Due to impairments in awareness in persons with dementia (5), (I)ADL functioning has traditionally been assessed using study partner-report questionnaires (6-14). However, it has been suggested that study partner-report may be influenced by study partner depression, anxiety and caregiver burden (15-17). With a shift towards studying cognitively normal or "at risk" individuals, one might assume that participants are able to reliably reflect on their own level of functioning, as they are thought to have accurate or potentially heightened awareness of their functional and cognitive abilities $(5,18)$. In such populations, participant-report may therefore be a more appropriate and direct assessment method in cognitively normal individuals $(12,15,17)$.

The validity of participant-reported IADL in preclinical or "at risk" populations is not yet clear. Alterations in awareness may already occur in preclinical populations and may lead to discordance between participants and study partners, where one may report more or less impairments than the other. Only few studies compared participant with study partner-reported functioning in communitybased populations $(11,19)$. Studies in patients with dementia or $\mathrm{MCl}$ seem to indicate that there is a greater chance of discordance when participants have depressive symptoms or lower objective cognition (12,19-22), and that discordance decreased when participant and study partner are living together (16). Studies investigating the interplay of these factors in cognitively normal populations are scarce. Furthermore, findings are difficult to compare between studies, due to differences in IADL measurements and in the definition and operationalization of concordance and discordance.

The Amsterdam IADL Questionnaire (A-IADL-Q) was developed as a study partner-rated questionnaire, and has been extensively validated in memory clinic and international aging 
medRxiv preprint doi: https://doi.org/10.1101/2021.11.01.21265650; this version posted November 2, 2021. The copyright holder for this preprint (which was not certified by peer review) is the author/funder, who has granted medRxiv a license to display the preprint in It is made available under a CC-BY-NC-ND 4.0 International license .

RUNNING TITLE: Everyday functioning: Differences between dyads

populations $(20,23-30)$. It is not yet known how the participant-report version of the A-IADL-Q performs, and how it relates to study-partner report. The aim of this study is to investigate how the participant- and study partner-reported versions of the A-IADL-Q perform in a community-based population, without dementia. Second, we aim to investigate what factors relate to differences between participant- and study partner-reported IADL functioning. 
medRxiv preprint doi: https://doi.org/10.1101/2021.11.01.21265650; this version posted November 2, 2021. The copyright holder for this preprint (which was not certified by peer review) is the author/funder, who has granted medRxiv a license to display the preprint in It is made available under a CC-BY-NC-ND 4.0 International license .

RUNNING TITLE: Everyday functioning: Differences between dyads

\section{Materials and Methods}

\section{Participant selection and study design}

Participants were recruited through the Dutch online brain research registry (Hersenonderzoek.nl), which is an online platform for people interested in cognition and brain-related research (31). All eligible registrants were invited by e-mail to participate in the study. The only inclusion criterion was being 18 years or older. Those who self-reported to have received a dementia-related diagnosis (i.e., dementia or mild cognitive impairment $[\mathrm{MCl}])$ were excluded.

Data collection started in August 2018 and ended in December 2018. The study was approved by the medical ethical committee of the VU University Medical Center. The participants provided consent via Hersenonderzoek.nl. Since study partners were not recruited through Hersenonderzoek.nl, they provided consent prior to completing the online IADL questionnaire.

\section{Measures}

Amsterdam IADL Questionnaire

The main outcome measure was the Amsterdam IADL Questionnaire (A-IADL-Q). The A-IADL-Q was developed as a study partner-report instrument aimed at measuring problems in cognitively complex everyday functioning (23). For the current study, we adapted the study partner-report version to a participant-report version. Both versions consist of the same 30 items, covering a broad range of cognitive IADLs. Each item assesses difficulty performing an activity due to cognitive problems, such as memory, attention, or executive functioning. Item responses were rated on a five-point Likert scale, ranging from "no difficulty in performing this activity" $(0)$ to "no longer able to perform this activity" (4). The total score is calculated using item response theory (IRT), assuming a single underlying construct (32), that is, IADL functioning, ranging from disability to ability. Total scores range from 20 to 70 , and were reversed so that higher scores reflect better IADL functioning. A cutoff for dementia was previously placed at 51.4 (24), while scores above 60 were considered to indicate no IADL difficulties (33). The study partner-report version of the A-IADL-Q has undergone extensive validation, showing good content and construct validity, high internal consistency, high test-retest reliability, good responsiveness to change and able to measure IADL across cultures and languages $(20,24-26,29)$. The study partner version of the A-IADL-Q also includes questions about the type of relation to the participant and cohabitation. Study partners 
medRxiv preprint doi: https://doi.org/10.1101/2021.11.01.21265650; this version posted November 2, 2021. The copyright holder for this preprint (which was not certified by peer review) is the author/funder, who has granted medRxiv a license to display the preprint in It is made available under a CC-BY-NC-ND 4.0 International license .

RUNNING TITLE: Everyday functioning: Differences between dyads

were classified as spouses, children, siblings or 'other'. Study partners in the 'other' category included friends, coworkers, or other family members.

\section{Other measures}

Cognitive functioning was assessed using the Cognitive Online Self-Test Amsterdam (COST-A), an online cognitive self-test developed and validated by Van Mierlo et al. (34). The COST-A included 10 tasks, covering multiple cognitive domains. Performance on each of the 10 tasks was standardized into a Z-score, where higher scores indicate better cognition. These Z-scores were averaged into a global score representing overall cognitive functioning. Visser et al. (2021) provides a more detailed description of the COST-A.

Additionally, a single yes/no question ("Do you have memory complaints?") assessed subjective memory complaints. Depressive symptoms were assessed with the five-item short form of the Geriatric Depression Scale (GDS5) (35). with higher scores indicating more depressive symptoms. Education level was classified as low-medium (up to high school) and high education (college degree).

\section{Defining awareness of IADL functioning}

In line with other studies, we defined concordance based on the discrepancy between participantand study partner-report (5). We categorized concordance into three groups, based on a previously determined clinically meaningful difference of 2.4 points (36): (1) concordance between dyads; (2) discordance between dyads with the participant 'over reporting' difficulties (i.e., scoring $\geq 2.4$ points lower than their study partner); and (3) discordance between dyads with the participant 'underreporting' difficulties (i.e., scoring $\geq 2.4$ points higher than their study partner).

\section{Statistical analyses}

Demographic differences between study partners and participants were tested using independent t-tests or chi-square tests. The frequency of IADL difficulties among cognitively normal participants and their study partners was determined. Then, in separate linear regression analyses, A-IADL-Q scores of both raters were associated with age, education, objective cognitive functioning, subjective cognitive functioning, and depressive symptoms. 
medRxiv preprint doi: https://doi.org/10.1101/2021.11.01.21265650; this version posted November 2, 2021. The copyright holder for this preprint (which was not certified by peer review) is the author/funder, who has granted medRxiv a license to display the preprint in It is made available under a CC-BY-NC-ND 4.0 International license .

RUNNING TITLE: Everyday functioning: Differences between dyads

The intraclass correlation coefficient (ICC) was computed to examine concordance between participants and study partner ratings. According to the criteria of Koo et al., an ICC $<.5$ shows poor concordance, an ICC of .5-.75 shows moderate, and $>.75$ shows good concordance (37).

Using stepwise multinomial logistic regression models with backward selection, we investigated which factors related to concordance and discordance between dyads. The included variables were participants' education level, sex, age, COST-A scores, memory complaints, and GDS5 total score, study partner-reported IADL functioning, the type of relationship, cohabitation (yes/no), and the absolute age difference between dyads. For this analysis, COST-A scores were dichotomized into normal (>-1.5SD) and low ( $\leq-1.5 \mathrm{SD})$ cognitive functioning. All analyses were performed in $\mathrm{R}$ version 4.0.3 (38). 
medRxiv preprint doi: https://doi.org/10.1101/2021.11.01.21265650; this version posted November 2, 2021. The copyright holder for this preprint (which was not certified by peer review) is the author/funder, who has granted medRxiv a license to display the preprint in It is made available under a CC-BY-NC-ND 4.0 International license

RUNNING TITLE: Everyday functioning: Differences between dyads

\section{Results}

Of the 11,060 eligible registrants, 4,817 individuals (44\%) were interested in participation and received study instructions. After receiving instructions, 3,288 (68\%) completed the participantreported A-IADL-Q. On average, participants were $61.0 \pm 12.1$ years old and the majority were female $(2,315 ; 70.4 \%)$. Approximately half the participants experienced memory complaints. Table 1 displays all participant and study partner characteristics.

For 1,213 participants (36.9\% of complete sample), the A-IADL-Q was also completed by a studypartner (participant and study partner pairs will be referred to as 'dyads'). Participants who were part of a dyad were older $(p<.001)$ and were more often male $(p=.046)$ than those who were not. Within dyads, the participants were older $(p<.001)$ and more likely to be female $(p<.001)$, compared to study partners.

Table 1. Participant and study partner characteristics

\begin{tabular}{|c|c|c|c|}
\hline & \multirow[t]{2}{*}{$\begin{array}{l}\text { Participants } \\
(\mathrm{N}=\mathbf{3 , 2 8 8})\end{array}$} & \multicolumn{2}{|c|}{$\begin{array}{c}\text { Dyads } \\
(\mathrm{N}=1,213)\end{array}$} \\
\hline & & Participants & $\begin{array}{c}\text { Study } \\
\text { partners }\end{array}$ \\
\hline $\begin{array}{l}\text { Age, mean (SD) } \\
\text { Range }\end{array}$ & $\begin{array}{l}61.0(12.1) \\
18-97\end{array}$ & $\begin{array}{l}62.5(11.1) \\
18-93\end{array}$ & $\begin{array}{c}58.8(14.2) \\
18-88\end{array}$ \\
\hline Female, n (\%) & $2,315(70.4)$ & $828(68.3)$ & $556(45.8)$ \\
\hline High level of education, $\mathrm{n}(\%)$ & $2,323(70.7)$ & $854(70.4)$ & - \\
\hline $\begin{array}{l}\text { A-IADL-Q score, mean (SD) } \\
\text { Range }\end{array}$ & $\begin{array}{l}65.9(4.8) \\
40.9-70.0\end{array}$ & $\begin{array}{l}65.9(4.7) \\
40.7-70.0\end{array}$ & $\begin{array}{l}66.1(4.6) \\
42.7-70.0\end{array}$ \\
\hline $\begin{array}{l}\text { Memory complaints present, }{ }^{1} \mathrm{n} \\
(\%)\end{array}$ & $1,429(47.5)$ & $586(49.9)$ & - \\
\hline $\begin{array}{l}\text { COST-A, }{ }^{2} \text { abnormal } \\
\text { performance ( } \leq-1.5 \mathrm{SD}), \mathrm{n}(\%)\end{array}$ & $225(7.6)$ & $86(7.5)$ & - \\
\hline GDS5,${ }^{1}$ median $(\mathrm{IQR})$ & $0(0-1)$ & $0(0-1)$ & - \\
\hline $\begin{array}{l}\text { Type of relationship, n (\%) } \\
\text { Spouse } \\
\text { Child } \\
\text { Sibling } \\
\text { Other }\end{array}$ & & \multicolumn{2}{|c|}{$\begin{array}{c}956(78.8) \\
155(12.8) \\
32(2.6) \\
70(5.8)\end{array}$} \\
\hline $\begin{array}{l}\text { Duration relationship, } \mathrm{n}(\%) \\
<5 \text { years } \\
5-10 \text { years } \\
>10 \text { years }\end{array}$ & & \multirow{2}{*}{\multicolumn{2}{|c|}{$\begin{array}{c}33(2.7) \\
58(4.8) \\
1,119(92.5) \\
960(79.3)\end{array}$}} \\
\hline Living together, n (\%) & & & \\
\hline
\end{tabular}

'-' denotes that data was not available. ${ }^{1}$ Data available for 3,011 participants, 1,175 of whom were part of a dyad. ${ }^{2}$ Data available for 2,945 participants, 1,149 of whom were part of a dyad. 
medRxiv preprint doi: https://doi.org/10.1101/2021.11.01.21265650; this version posted November 2, 2021. The copyright holder for this preprint (which was not certified by peer review) is the author/funder, who has granted medRxiv a license to display the preprint in It is made available under a CC-BY-NC-ND 4.0 International license

RUNNING TITLE: Everyday functioning: Differences between dyads

Abbreviations: A-IADL-Q, Amsterdam Instrumental Activities of Daily Living Questionnaire; COST-A, Cognitive Self-Test Amsterdam; GDS5, 5-item Geriatric Depression Scale; IQR, interquartile range; SD, standard deviation.

IADL difficulties in a cognitively normal population

Figure 1 shows the distribution among dyads of participant- and study partner-reported A-IADL-Q scores. The participant-reported A-IADL-Q scores $(65.9 \pm 4.8)$ did not differ from the study partnerreported A-IADL-Q scores $(66.1 \pm 4.6 ; p=.186)$. Virtually all participants $(3,232 / 3,288 ; 98.3 \%)$ and study partners $(1,195 / 1,213 ; 98.5 \%)$ reported A-IADL-Q scores above a previously established cutoff for dementia (total score of 51.4). Moreover, the vast majority of both participant-reported $(87.9 \%)$ and study partner-reported $(89.4 \%)$ total scores where higher than 60 , indicating no difficulties.

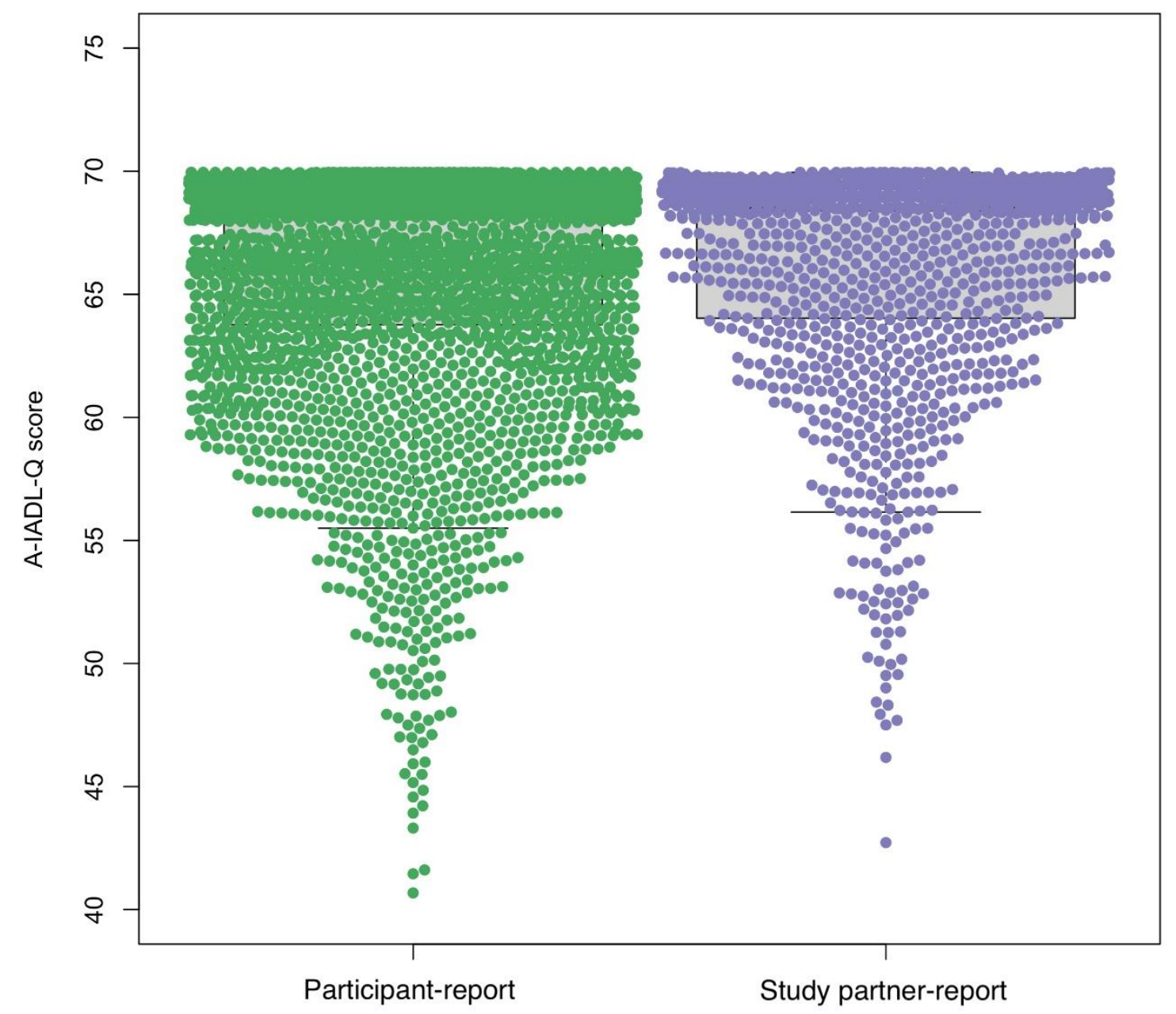

Figure 1. A-IADL-Q total score distribution among participants $(N=3,288$, in green) and study partners ( $N=1,213$, in purple). 
medRxiv preprint doi: https://doi.org/10.1101/2021.11.01.21265650; this version posted November 2, 2021. The copyright holder for this preprint (which was not certified by peer review) is the author/funder, who has granted medRxiv a license to display the preprint in It is made available under a CC-BY-NC-ND 4.0 International license .

RUNNING TITLE: Everyday functioning: Differences between dyads

Next, we looked at IADL difficulties at item level. Half of all participants $(1,750 / 3,288,53.2 \%)$ and study partners $(722 / 1,213,59.5 \%)$ reported no difficulties in any activity. Those who did report difficulties, mostly did so in only one activity (35.2\% of participants, $35.8 \%$ of study partners). Error! Reference source not found. shows the percentage of participants and study partners who reported difficulties for each IADL activity. Most frequently reported IADL difficulties for both participants and study partners were working (26.9\% and $19.9 \%$, respectively), household duties (22.2\% and $16.5 \%$, respectively) and making minor repairs at home $(16.4 \%$ and $12.7 \%$, respectively). 
medRxiv preprint doi: https://doi.org/10.1101/2021.11.01.21265650; this version posted November 2, 2021. The copyright holder for this preprint (which was not certified by peer review) is the author/funder, who has granted medRxiv a license to display the preprint in It is made available under a CC-BY-NC-ND 4.0 International license .

RUNNING TITLE: Everyday functioning: Differences between dyads

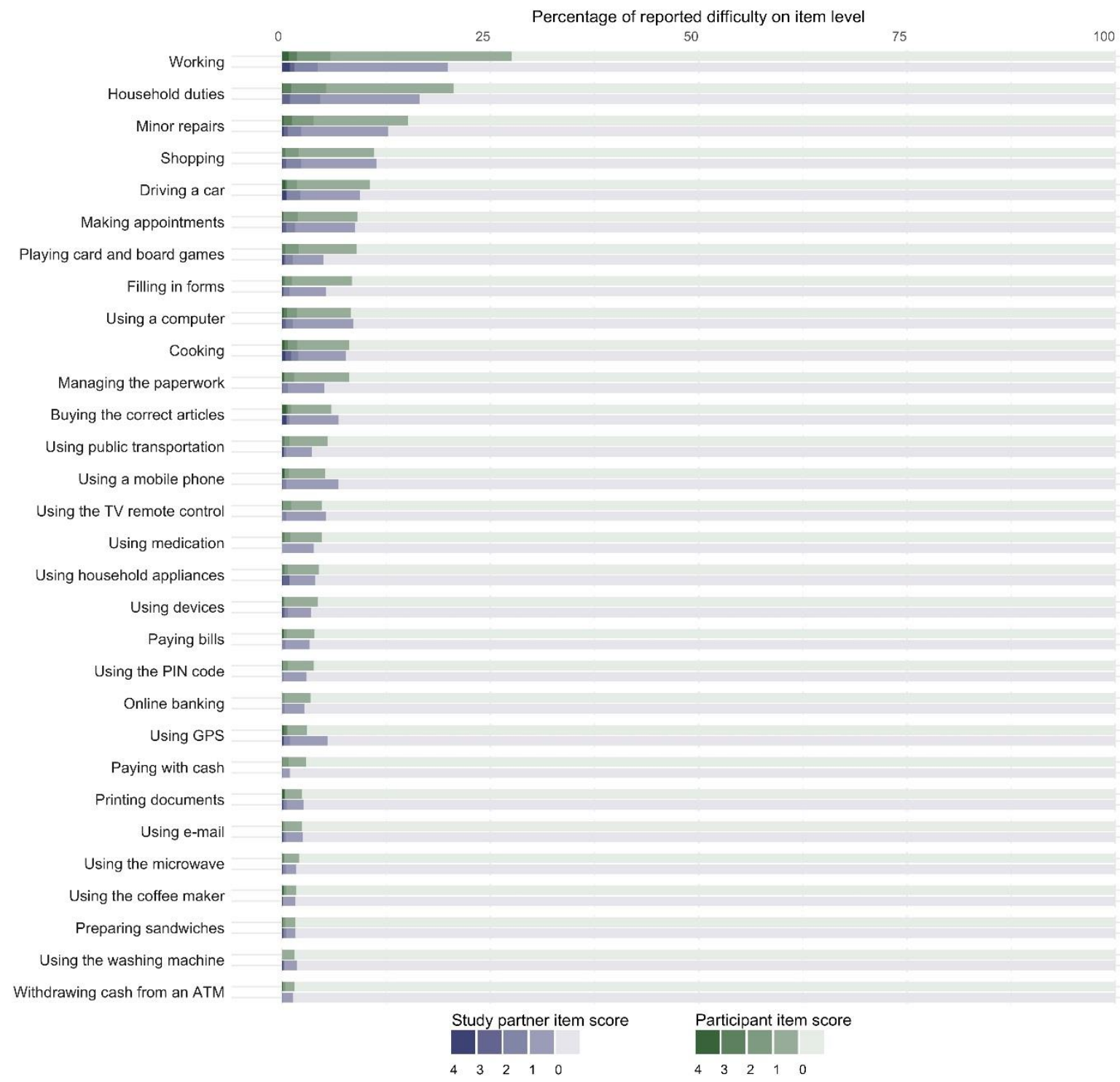

Figure 2. Stacked bar chart showing the percentage of participants (in shades of green) and study partners (in shades of purple) who reported difficulties ( $N=1,213)$.

The dark shades represent difficulty with the activity: "no longer able to perform this activity" (4), "much more difficulty" (3), "more difficulty" (2), and "slightly more difficulty" (1). The lightest shade represents "no difficulty in performing this activity" (0).

Table 2 shows the associations between age, education level, cognitive complaints, COST-A, GDS and participant- and study partner-reported IADL performance. Higher age was associated with lower A-IADL-Q scores, and higher education with better A-IADL-Q scores, but associations were weak. For example, with every 10 years increase in age, A-IADL-Q participant- and study partnerreported scores decreased with 1.2 and 1.8 points, respectively. Both participant- and study 
medRxiv preprint doi: https://doi.org/10.1101/2021.11.01.21265650; this version posted November 2, 2021. The copyright holder for this preprint (which was not certified by peer review) is the author/funder, who has granted medRxiv a license to display the preprint in It is made available under a CC-BY-NC-ND 4.0 International license .

RUNNING TITLE: Everyday functioning: Differences between dyads

partner-reported A-IADL-Q scores were more highly associated with COST-A scores, memory complaints, and GDS. Higher COST-A scores, indicating better cognitive functioning, were associated with better IADL functioning, whereas a higher GDS, indicating more depressive symptoms, and presence of memory complaints were associated with worse IADL functioning. Associations with age, education and COST-A scores were comparable for participant- and study partner-report, whereas associations with GDS and memory complaints were more strongly associated with participant-reported IADL scores.

Table 2. Linear regressions to investigate associations with participant- and study partner-reported IADL performance

\begin{tabular}{|c|c|c|c|c|}
\hline \multirow{2}{*}{ Measure } & \multicolumn{2}{|c|}{ Participant-report } & \multicolumn{2}{|c|}{ Study partner-report } \\
\hline & $N$ & $\begin{array}{c}\text { Standardized } \\
\text { beta }\end{array}$ & $N$ & $\begin{array}{c}\text { Standardized } \\
\text { beta }\end{array}$ \\
\hline Age & 3,288 & $-.12[-.16,-.09]$ & 1,213 & $-.18[-.26,-.14]$ \\
\hline High education & 3,288 & $.09[.06, .13]$ & 1,213 & $.07[.02, .13]$ \\
\hline Memory complaints present & 3,011 & $-.33[-.36,-.29]$ & 1,175 & $-.24[-.30,-.19]$ \\
\hline COST-A & 2,945 & $.23[.19, .26]$ & 1,149 & $.25[.20, .31]$ \\
\hline GDS5 & 3,017 & $-.33[-.36,-.29]$ & 1,177 & $-.21[-.30,-.17]$ \\
\hline
\end{tabular}

Associations are shown as standardized beta [95\% confidence interval].

Abbreviations: A-IADL-Q, Amsterdam Instrumental Activities of Daily Living Questionnaire; COST-A, Cognitive Online Self-test Amsterdam; GDS5, Geriatric Depression Scale - 5 item version. Education level was classified as low-medium (up to high school) and high education (college degree).

\section{Concordance and discordance between dyads}

There was a moderate consistency between participant- and study partner-reported IADL functioning (intraclass correlation coefficient $=.55,95 \% \mathrm{Cl}=[.51, .59], p<.001$; see Supplementary Figure 1). Of all 1,213 dyads, 700 (57.7\%) were in concordance. Two hundred sixteen participants (17.8\%) underreported difficulties, compared to their study partners, and 297 participants (24.5\%) over reported IADL difficulties, compared to their study partners. Compared to concordant dyads, participants with memory complaints (odds ratio $(\mathrm{OR})=2.44,95 \% \mathrm{Cl}=[1.80,3.32], p<.001$ ) and with a higher $\mathrm{GDS}(\mathrm{OR}=1.31,95 \% \mathrm{Cl}=[1.12,1.53], p=.001)$ were more likely to overreport IADL difficulties. Participant underreport was less likely when there were fewer IADL difficulties $(O R=$ $0.71,95 \% \mathrm{Cl}=[0.67,0.74], p<.001)$. Thus, concordance was more likely when the participant did not experience memory complaints, had lower GDS scores and when IADL performance was 
medRxiv preprint doi: https://doi.org/10.1101/2021.11.01.21265650; this version posted November 2, 2021. The copyright holder for this preprint (which was not certified by peer review) is the author/funder, who has granted medRxiv a license to display the preprint in It is made available under a CC-BY-NC-ND 4.0 International license

RUNNING TITLE: Everyday functioning: Differences between dyads

higher. Participant's education, age, gender and COST-A scores were not related to concordance between dyads.

Table 3. Multivariable multinomial logistic regression models comparing study partners reporting more $I A D L$ difficulties than participant $(N=216)$ and participant reporting more IADL difficulties than study partner ( $N=297)$, compared to agreement between participant and study partner $(N=700)$.

\section{Predictor}

\section{Study partner > Participant}

$(\mathrm{N}=216)$
Participant $>$ study partner

$(\mathrm{N}=297)$

\begin{tabular}{|c|c|c|c|c|}
\hline & OR $[95 \% \mathrm{Cl}]$ & $\mathbf{P}$ & OR $[95 \% \mathrm{Cl}]$ & $\mathbf{P}$ \\
\hline COST-A $\leq-1.5$ SD & $0.47[0.21,1.07]$ & .070 & $1.36[0.78,2.39]$ & .283 \\
\hline A-IADL-Q (study partner-report) & $0.71[0.67,0.74]$ & $<.001$ & $1.04[0.99,1.09]$ & .148 \\
\hline Memory complaints present & $0.76[0.50,1.15]$ & .194 & $2.44[1.80,3.32]$ & $<.001$ \\
\hline High education & $0.92[0.60,1.40]$ & .689 & $1.30[0.93,1.80]$ & .121 \\
\hline $\begin{array}{l}\text { Absolute age difference between dyads } \\
\text { in years }\end{array}$ & $1.00[0.97,1.04]$ & .924 & $1.01[0.98,1.04]$ & .924 \\
\hline Age in years (participant) & $1.01[0.99,1.03]$ & .467 & $1.01[0.99,1.02]$ & .272 \\
\hline Female sex (participant) & $0.74[0.53,1.02]$ & .159 & $1.08[0.78,1.49]$ & .661 \\
\hline GDS5* & $0.58[0.50,0.68]$ & $<.001$ & $1.31[1.12,1.53]$ & $<.001$ \\
\hline Type of relationship, study partner is a: ${ }^{\dagger}$ & $2.19[0.63,7.60]$ & .216 & $0.83[0.30,2.27]$ & .716 \\
\hline Child & $0.75[0.13,4.35]$ & .744 & $0.57[0.18,1.85]$ & .350 \\
\hline Sibling & $0.81[0.22,2.98]$ & .755 & $0.63[0.24,1.68]$ & .355 \\
\hline \multicolumn{5}{|l|}{ Other } \\
\hline Dyads live together & $1.58[0.70,3.57]$ & .277 & $1.04[0.57,1.90]$ & .898 \\
\hline
\end{tabular}

Abbreviations: COST-A, Cognitive Online Self-Test Amsterdam; GDS5, 5-item short form of Geriatric Depression Scale; OR, odds ratio; $95 \% \mathrm{Cl}$, 95\% confidence interval. Concordance was used as a reference group $(N=700) . *$ more depressive symptoms; † Using spouse as a reference category. 
medRxiv preprint doi: https://doi.org/10.1101/2021.11.01.21265650; this version posted November 2, 2021. The copyright holder for this preprint (which was not certified by peer review) is the author/funder, who has granted medRxiv a license to display the preprint in It is made available under a CC-BY-NC-ND 4.0 International license .

RUNNING TITLE: Everyday functioning: Differences between dyads

\section{Discussion}

In this study, we showed that the majority of IADL scores fell within the range of normal IADL functioning in this community-based population, but that discordance among dyads was quite prevalent. A small subgroup reported subtle IADL difficulties, which was associated with participants' older age, lower education, worse cognitive performance, presence of memory complaints, and more depressive symptoms, for both participant and study partner-report. Moderate concordance between participant and study partner-reported IADL was found with discordance being more likely when the participant experienced memory complaints, depressive symptoms, and lower IADL performance.

Whilst the large majority of participant and study partner-reported IADL functioning fell within the range of normal IADL functioning, approximately a tenth of both participants and study partners scored below the previously established cutoff for normal IADL functioning (33). This prevalence of impaired IADL is comparable to other population-based studies (21, 39-41). For example, ScheelHincke and colleagues (40) reported a prevalence of impaired IADL of 12 to $20 \%$ in Western Europe, with impaired IADL defined as presence of any difficulties. Another population-based study by Pudaric and colleagues (41) reported a prevalence of impaired IADL (inability to carry out shopping, cooking or housework) of 6 to $11 \%$. Despite this comparable prevalence of abnormal IADL functioning, it is important to note that approximately half of our population reported more subtle difficulties. If we applied the definition of Scheel-Hincke et al. (40), the prevalence of impaired IADL in our study would be approximately $50 \%$, which is substantially higher than the prevalence that they reported. There are two potential explanations for this difference: first, we included more activities, and, second and more importantly, we included more cognitively complex activities than other studies. This is illustrated by the fact that most problems were reported in working, household duties and making repairs, which are especially cognitively complex (26). These activities were not reported for other IADL scales. For example, a population-based study which assessed five IADL items (42), reported most problems for shopping. In our population, problems with shopping was fourth most prevalent. We found a higher proportion of difficulties for more complex activities, supporting the notion that including more complex activities enabled detection of more fine-grained difficulties in IADL functioning. 
medRxiv preprint doi: https://doi.org/10.1101/2021.11.01.21265650; this version posted November 2, 2021. The copyright holder for this preprint (which was not certified by peer review) is the author/funder, who has granted medRxiv a license to display the preprint in It is made available under a CC-BY-NC-ND 4.0 International license .

RUNNING TITLE: Everyday functioning: Differences between dyads

With regard to potential sources of bias in the report of IADL functioning, we found low associations between both study partner and participant-reported IADL functioning and age and education, a finding which is in line with previous validation studies for the study partner version of the A-IADLQ (20, 26, 29). Participant- and study partner-report were similarly associated with objective cognitive performance, but participant-report was more strongly related to depressive symptoms as well as subjective cognitive performance (i.e., presence of memory complaints). Consistent with recent literature suggesting that study partners are better able to assess the participants' functioning than the participant themselves (43), our findings imply that study partner-report might be less biased than participant-report by participant-related subjective factors.

Our findings demonstrated only a moderate concordance between dyads. While the distributions of study partner- and participant-reported IADL scores were largely similar, we found a moderate ICC, and a high proportion of discordance (either over or underreport). Other studies have also shown discordance in cognitively normal participants, and specifically participant overreport (11, 19, 21, 44). For example, a study by Okonkwo and colleagues (19) showed slight discordance between participant and study partner-report of specific finance-related IADLs. The proportion of discordance that we found in our study is substantially higher, which is probably due to differences in IADL measures, definitions of concordance and population differences. As opposed to Okonkwo and colleagues (19), who calculated concordance based on an individual item, we determined concordance based on a more global measure of IADL with a wider range of activities. We calculated concordance based on a clinical meaningful difference in total scores. Another potential explanation may be that, even though we used a population-based sample, we did not screen for cognitive impairment. As such, it is possible that there were participants who had subtle cognitive impairment, but did not meet criteria for $\mathrm{MCl}$ or dementia. Thus, while the proportion of discordance is difficult to compare to other studies, the fact that other studies also reported discordance, suggests that participant and study partner report might not be interchangeable.

The potential limited interchangeability is further supported by our results which indicate that concordance is influenced by memory complaints and depressive symptoms. Participants with memory complaints reported more difficulties, compared to their study partners. Participant 
medRxiv preprint doi: https://doi.org/10.1101/2021.11.01.21265650; this version posted November 2, 2021. The copyright holder for this preprint (which was not certified by peer review) is the author/funder, who has granted medRxiv a license to display the preprint in It is made available under a CC-BY-NC-ND 4.0 International license .

RUNNING TITLE: Everyday functioning: Differences between dyads

overreport of memory complaints has previously been described as a heightened awareness (5), which is thought to characterize early stages of Alzheimer's disease and related disorders $(5,45$, 46). Following this theory, a subgroup of our study sample may have a heightened functional awareness. This idea is further supported by our finding that a large proportion of our sample had memory complaints, which may indicate a heightened memory awareness. While no other studies have investigated the effect of subjective cognitive functioning on the concordance of functional impairment, several studies $(11,19,21,44,47-49)$ related objective cognitive functioning to concordance. These studies show that patients with poorer global cognition are more likely to underreport IADL difficulties. We did not find an significant association between concordance and objective cognition within our healthy volunteer population. This could be due to the fact that our population is presumably cognitively healthy, and lowered awareness may not occur until later disease stages $(5,50)$. Although not significant, in this population, lower cognitive performance seems to be related to a reduced odds for participant underreport. This might suggest that the subtle cognitive problems of these individuals do not interfere with their disease insight, but rather, that they increase their awareness. Furthermore, participants with depressive symptoms were more likely to overreport, and less likely to underreport, IADL difficulties. This is in line with the idea that negative self-perception in patients with depressive symptoms causes exaggeration of deficits (51), as has also been shown by Okonkwo and colleagues (19), who reported that underestimation of financial abilities was related to higher depressive symptoms. Thus, memory complaints and depressive symptoms both influence the participant's report of their IADL difficulties, and need to be taken into consideration when using participant-reported IADL measures.

The findings discussed above may have important implications for study design decisions and should be considered carefully when considering the use of a participant-reported IADL instrument. Although a concordance of $60 \%$ might seem low, the majority of both participant and study partnerreported difficulties fell within the category of 'no difficulties'. This crude overlap indicates that participant-report IADL can be useful in cognitively normal populations in cross-sectional studies. However, when a deterioration of cognitive functioning and subsequently everyday functioning is to be expected, study partner-report might provide a more reliable indication of change in IADL 
medRxiv preprint doi: https://doi.org/10.1101/2021.11.01.21265650; this version posted November 2, 2021. The copyright holder for this preprint (which was not certified by peer review) is the author/funder, who has granted medRxiv a license to display the preprint in It is made available under a CC-BY-NC-ND 4.0 International license .

RUNNING TITLE: Everyday functioning: Differences between dyads

functioning. The combination of participant- and study partner-report can be used to establish awareness, which is informative since it has been shown to predict future disease progression (52, 53) and greater discordance seems to be related to a greater risk of Alzheimer pathology $(5,47)$. Thus, participant self-report can be used in cognitively normal populations, but should ideally be supplemented by study partner-report for longitudinal studies.

Some limitations should be considered when interpreting our findings. For lack of an objective IADL measure, we cannot ascertain whether participants indeed overreport their difficulties, or whether participants actually have IADL difficulties that the study partner does not yet notice. In other words, a heightened participant awareness may also reflect lowered study partner awareness. This caveat notwithstanding, the absence of an association with objective cognitive functioning could indicate that participant overreport is more strongly influenced by subjective than objective factors. Further, as study-partner report is generally considered a gold standard in dementia research and clinical practice (54), we used it as such in the current study. Another limitation is the selective nature of the volunteer registry, which consists mostly of highly educated and highly motivated individuals. This may limit generalizability to the general population. We did not include factors such as caregiver burden, personality traits or more detailed information on the amount of contact between the participant and the study partner. Future studies should consider to assess these factors to obtain more detailed insight into the accuracy of assessments and possible biases. Furthermore, follow-up studies are needed to determine the pivot point until which the participant is still able to reliably evaluate their own level of daily functioning.

An important strength of this study is the large sample of cognitively healthy volunteers, representing a large range of ages, from early adulthood to late life. We included detailed information about the level of IADL difficulties from both self and study partner-report in a cognitively healthy population, providing valuable new insights into the occurrence of more subtle IADL difficulties. Another strength is our use of a clinically meaningful cutoff to distinguish concordance from discordance. For this reason, we believe that discordance actually represented an important, non-negligible difference in IADL report. 
medRxiv preprint doi: https://doi.org/10.1101/2021.11.01.21265650; this version posted November 2, 2021. The copyright holder for this preprint (which was not certified by peer review) is the author/funder, who has granted medRxiv a license to display the preprint in It is made available under a CC-BY-NC-ND 4.0 International license .

RUNNING TITLE: Everyday functioning: Differences between dyads

In conclusion, our findings show a moderate concordance between participants and study partners in reporting IADL difficulties, with subjective factors influencing the level of concordance. These findings suggest caution in using self- and study partner-report measures interchangeably, even in cognitively healthy community-based samples. Our results suggests that participant report might be more related to subjective factors and that study partner report is less associated with these factors, possibly reflecting differing perspectives.

\section{Acknowledgments}

We thank the participants and their study partners for their time and participation in our study. The participant recruitment was accomplished through Hersenonderzoek.nl, a Dutch online registry that facilitates participant recruitment for neuroscience studies (www.hersenonderzoek.nl). Hersenonderzoek.nl is funded by ZonMw-Memorabel (project no 73305095003), a project in the context of the Dutch Deltaplan Dementie, Gieskes-Strijbis Foundation, the Alzheimer's Society in the Netherlands and Brain Foundation Netherlands. Funding for the data collection and research on which this manuscript is based was provided by the Stichting Stoffels-Hornstra. 
medRxiv preprint doi: https://doi.org/10.1101/2021.11.01.21265650; this version posted November 2, 2021. The copyright holder for this preprint (which was not certified by peer review) is the author/funder, who has granted medRxiv a license to display the preprint in perpetuity. perpetuity. 4.0 International license.

RUNNING TITLE: Everyday functioning: Differences between dyads

\section{References}

1. Marshall GA, Aghjayan SL, Dekhtyar M, Locascio JJ, Jethwani K, Amariglio RE, et al. Activities of daily living measured by the Harvard Automated Phone Task track with cognitive decline over time in non-demented elderly. J Prev Alzheimers Dis. 2017;4(2):81-6.

2. Marshall GA, Amariglio RE, Sperling RA, Rentz DM. Activities of daily living: where do they fit in the diagnosis of Alzheimer's disease? Neurodegener Dis Manag. 2012;2(5):483-91.

3. Zoller AS, Gaal IM, Royer CA, Locascio JJ, Amariglio RE, Blacker D, et al. SIST-M-IR activities of daily living items that best discriminate clinically normal elderly from those with mild cognitive impairment. Curr Alzheimer Res. 2014;11(8):785-91.

4. Edgar CJ, Vradenburg G, Hassenstab J. The 2018 Revised FDA Guidance for Early Alzheimer's Disease: Establishing the Meaningfulness of Treatment Effects. J Prev Alz Dis. 2019;6.

5. Hanseeuw BJ, Scott MR, Sikkes SAM, Properzi M, Gatchel JR, Salmon E, et al. Evolution of anosognosia in alzheimer's disease and its relationship to amyloid. Ann Neurol. 2020;87(2):267-80.

6. Desai AK, Grossberg GT, Sheth DN. Activities of daily living in patients with dementia: clinical relevance, methods of assessment and effects of treatment. CNS Drugs. 2004;18(13):853-75.

7. Loewenstein DA, Arguelles S, Bravo M, Freeman RQ, Arguelles T, Acevedo A, et al. Caregivers' judgments of the functional abilities of the Alzheimer's disease patient: a comparison of proxy reports and objective measures. J Gerontol B Psychol Sci Soc Sci. 2001;56(2):P78-84.

8. Sikkes SAM, de Lange-de Klerk ES, Pijnenburg YAL, Scheltens P, Uitdehaag BM. A systematic review of Instrumental Activities of Daily Living scales in dementia: room for improvement. J Neurol Neurosurg Psychiatry. 2009;80(1):7-12.

9. Graham DP, Kunik ME, Doody R, Snow AL. Self-reported awareness of performance in dementia. Brain Res Cogn Brain Res. 2005;25(1):144-52.

10. Howorth P, Saper J. The dimensions of insight in people with dementia. Aging Ment Health. 2003;7(2):113-22.

11. Farias ST, Mungas D, Jagust W. Degree of discrepancy between self and other-reported everyday functioning by cognitive status: dementia, mild cognitive impairment, and healthy elders. Int $\mathrm{J}$ Geriatr Psychiatry. 2005;20(9):827-34.

12. DeBettignies BH, Mahurin RK, Pirozzolo FJ. Insight for impairment in independent living skills in Alzheimer's disease and multi-infarct dementia. J Clin Exp Neuropsychol. 1990;12(2):355-63.

13. Wadley VG, Harrell LE, Marson DC. Self- and informant report of financial abilities in patients with Alzheimer's disease: reliable and valid? J Am Geriatr Soc. 2003;51(11):1621-6.

14. Hackett K, Mis R, Drabick DAG, Giovannetti T. Informant Reporting in Mild Cognitive Impairment: Sources of Discrepancy on the Functional Activities Questionnaire. J Int Neuropsychol Soc. 2020;26(5):503-14.

15. Zanetti O, Geroldi C, Frisoni GB, Bianchetti A, Trabucchi M. Contrasting results between caregiver's report and direct assessment of activities of daily living in patients affected by mild and very mild dementia: the contribution of the caregiver's personal characteristics. J Am Geriatr Soc. 1999;47(2):196-202.

16. Ready RE, Ott BR, Grace J. Validity of informant reports about AD and MCl patients' memory. Alzheimer Dis Assoc Dis. 2004;18(1):11-6.

17. Arguelles S, Loewenstein DA, Eisdorfer C, Arguelles T. Caregivers' judgments of the functional abilities of the Alzheimer's disease patient: impact of caregivers' depression and perceived burden. $\mathrm{J}$ Geriatr Psychiatry Neurol. 2001;14(2):91-8.

18. Steward KA, Kennedy R, Erus G, Nasrallah IM, Wadley VG. Poor awareness of IADL deficits is associated with reduced regional brain volume in older adults with cognitive impairment. Neuropsychologia. 2019;129:372-8.

19. Okonkwo OC, Wadley VG, Griffith HR, Belue K, Lanza S, Zamrini EY, et al. Awareness of deficits in financial abilities in patients with mild cognitive impairment: going beyond self-informant discrepancy. Am J Geriatr Psychiatry. 2008;16(8):650-9.

20. Sikkes SAM, Knol DL, Pijnenburg YAL, de Lange-de Klerk ES, Uitdehaag BM, Scheltens P. Validation of the Amsterdam IADL Questionnaire(c), a new tool to measure instrumental activities of daily living in dementia. Neuroepidemiology. 2013;41(1):35-41.

21. Ostbye T, Tyas S, McDowell I, Koval J. Reported activities of daily living: Agreement between elderly subjects with and without dementia and their caregivers. Age Ageing. 1997;26(2):99-106.

22. Magaziner J, Bassett SS, Hebel JR, Gruber-Baldini A. Use of proxies to measure health and functional status in epidemiologic studies of community-dwelling women aged 65 years and older. Am J Epidemiol. 1996;143(3):283-92. 
medRxiv preprint doi: https://doi.org/10.1101/2021.11.01.21265650; this version posted November 2, 2021. The copyright holder for this preprint (which was not certified by peer review) is the author/funder, who has granted medRxiv a license to display the preprint in perpetuity. perpetuity. 4.0 International license.

RUNNING TITLE: Everyday functioning: Differences between dyads

23. Sikkes SAM, de Lange-de Klerk ES, Pijnenburg YAL, Gillissen F, Romkes R, Knol DL, et al. A new informant-based questionnaire for instrumental activities of daily living in dementia. Alzheimers Dement. 2012;8(6):536-43.

24. Sikkes SAM, Pijnenburg YAL, Knol DL, de Lange-de Klerk ES, Scheltens P, Uitdehaag BM. Assessment of instrumental activities of daily living in dementia: diagnostic value of the Amsterdam Instrumental Activities of Daily Living Questionnaire. J Geriatr Psychiatry Neurol. 2013;26(4):244-50.

25. Koster N, Knol DL, Uitdehaag BM, Scheltens P, Sikkes SAM. The sensitivity to change over time of the Amsterdam IADL Questionnaire((c)). Alzheimers Dement. 2015;11(10):1231-40.

26. Jutten RJ, Peeters CFW, Leijdesdorff SMJ, Visser PJ, Maier AB, Terwee CB, et al. Detecting functional decline from normal aging to dementia: Development and validation of a short version of the Amsterdam IADL Questionnaire. Alzheimers Dement (Amst). 2017;8:26-35.

27. Facal D, Carabias MAR, Pereiro AX, Lojo-Seoane C, Campos-Magdaleno M, Jutten RJ, et al. Assessing everyday activities across the dementia spectrum with the Amsterdam IADL Questionnaire. Curr Alzheimer Res. 2018;15(13):1261-6.

28. Villeneuve SC, Houot M, Cacciamani F, Verrijp M, Dubois B, Sikkes S, et al. Latent class analysis identifies functional decline with Amsterdam IADL in preclinical Alzheimer's disease. Alzheimers Dement (N Y). 2019;5:553-62.

29. Dubbelman MA, Verrijp M, Facal D, Sanchez-Benavides G, Brown LJE, van der Flier WM, et al. The influence of diversity on the measurement of functional impairment: An international validation of the Amsterdam IADL Questionnaire in eight countries. Alzheimers Dement (Amst). 2020;12(1):e12021. 30. Bruderer-Hofstetter M, Dubbelman MA, Meichtry A, Koehn F, Munzer T, Jutten RJ, et al. Crosscultural adaptation and validation of the Amsterdam Instrumental Activities of Daily Living questionnaire short version German for Switzerland. Health Qual Life Outcomes. 2020;18(1):323.

31. Zwan MD, van der Flier WM, Cleutjens S, Schouten TC, Vermunt L, Jutten RJ, et al. Dutch Brain Research Registry for study participant recruitment: Design and first results. Alzheimers Dement (N Y). 2021;7(1):e12132.

32. Reise SP, Waller NG. Item response theory and clinical measurement. Annu Rev Clin Psychol. 2009;5:27-48.

33. Dubbelman MA, Verrijp M, Visser LNC, Terwee CB, van Der Flier W, Scheltens P, et al. A mixedmethods approach to establish clinically meaningful categories of impairment in instrumental activities of daily living. Alzheimer's \& Dementia. 2020;16(S9).

34. Van Mierlo LD, Wouters H, Sikkes SAM, Van der Flier WM, Prins ND, Bremer JAE, et al. Screening for mild cognitive impairment and dementia with automated, anonymous online and telephone cognitive self-tests. J Alzheimers Dis. 2017;56(1):249-59.

35. Hoyl MT, Alessi CA, Harker JO, Josephson KR, Pietruszka FM, Koelfgen M, et al. Development and testing of a five-item version of the Geriatric Depression Scale. J Am Geriatr Soc. 1999;47(7):8738.

36. Abstract: Symposia, Conferences, Oral communications: 13th Clinical Trials on Alzheimer's Disease (CTAD) November 4-7, 2020. J Prev Alzheimers Dis. 2020;7(S1):S2-S54.

37. Koo TK, Li MY. A guideline of selecting and reporting intraclass correlation coefficients for reliability research. J Chiropr Med. 2016;15(2):155-63.

38. R Core Team. R: A language and environment for statistical computing. 4.0.2 ed2020.

39. Crimmins EM, Kim JK, Sole-Auro A. Gender differences in health: results from SHARE, ELSA and HRS. Eur J Public Health. 2011;21(1):81-91.

40. Scheel-Hincke LL, Moller S, Lindahl-Jacobsen R, Jeune B, Ahrenfeldt LJ. Cross-national comparison of sex differences in ADL and IADL in Europe: findings from SHARE. Eur J Ageing. 2020;17(1):69-79.

41. Pudaric S, Sundquist J, Johansson S-E. Country of birth, instrumental activities of daily living, self-rated health and mortality: a Swedish population-based survey of people aged 55-74. Social Science \& Medicine. 2003;56(12):2493-503.

42. Chan KS, Kasper JD, Brandt J, Pezzin LE. Measurement equivalence in ADL and IADL difficulty across international surveys of aging: findings from the HRS, SHARE, and ELSA. J Gerontol B Psychol Sci Soc Sci. 2012;67(1):121-32.

43. Howland M, Allan KC, Carlton CE, Tatsuoka C, Smyth KA, Sajatovic M. Patient-rated versus proxy-rated cognitive and functional measures in older adults. Patient Relat Outcome Meas. 2017;8:3342.

44. Pol MC, Buurman BM, de Vos R, de Rooij SE. Patient and proxy rating agreements on activities of daily living and the instrumental activities of daily living of acutely hospitalized older adults. J Am Geriatr Soc. 2011;59(8):1554-6. 
medRxiv preprint doi: https://doi.org/10.1101/2021.11.01.21265650; this version posted November 2, 2021. The copyright holder for this preprint (which was not certified by peer review) is the author/funder, who has granted medRxiv a license to display the preprint in It is made available under a perpetuity.

RUNNING TITLE: Everyday functioning: Differences between dyads

45. Slot RER, Sikkes SAM, Berkhof J, Brodaty H, Buckley R, Cavedo E, et al. Subjective cognitive decline and rates of incident Alzheimer's disease and non-Alzheimer's disease dementia. Alzheimers Dement. 2019;15(3):465-76.

46. Jessen F, Amariglio RE, Van Boxtel M, Breteler MMB, Ceccaldi M, Chételat G, et al. A conceptual framework for research on subjective cognitive decline in preclinical Alzheimer's disease. Alzheimers Dement. 2014;10(6):844-52.

47. Tabert MH, Albert SM, Borukhova-Milov L, Camacho Y, Pelton G, Liu X, et al. Functional deficits in patients with mild cognitive impairment: prediction of AD. Neurology. 2002;58(5):758-64.

48. Albert SM, Michaels K, Padilla M, Pelton G, Bell K, Marder K, et al. Functional significance of mild cognitive impairment in elderly patients without a dementia diagnosis. Am J Geriatr Psychiatry. 1999;7(3):213-20.

49. Weinberger M, Samsa GP, Schmader K, Greenberg SM, Carr DB, Wildman DS. Comparing proxy and patients' perceptions of patients' functional status: results from an outpatient geriatric clinic. $J$ Am Geriatr Soc. 1992;40(6):585-8.

50. Starkstein SE, Jorge R, Mizrahi R, Robinson RG. A diagnostic formulation for anosognosia in Alzheimer's disease. J Neurol Neurosurg Psychiatry. 2006;77(6):719-25.

51. Lahr D, Beblo T, Hartje W. Cognitive performance and subjective complaints before and after remission of major depression. Cogn Neuropsychiatry. 2007;12(1):25-45.

52. Nosheny RL, Jin C, Neuhaus J, Insel PS, Mackin RS, Weiner MW, et al. Study partner-reported decline identifies cognitive decline and dementia risk. Ann Clin Transl Neurol. 2019;6(12):2448-59.

53. Nosheny RL, Camacho MR, Jin C, Neuhaus J, Truran D, Flenniken D, et al. Validation of online functional measures in cognitively impaired older adults. Alzheimers Dement. 2020;16(10):1426-37.

54. Sikkes SAM, De Rotrou J. A qualitative review of instrumental activities of daily living in dementia: what's cooking? Neurodegener Dis Manag. 2014;4(5):393-400. 
medRxiv preprint doi: https://doi.org/10.1101/2021.11.01.21265650; this version posted November 2, 2021. The copyright holder for this preprint (which was not certified by peer review) is the author/funder, who has granted medRxiv a license to display the preprint in It is made available under a CC-BY-NC-ND 4.0 International license .

RUNNING TITLE: Everyday functioning: Differences between dyads

\section{Supplementary Material}

Relationship between participant and study partner-reported IADL scores

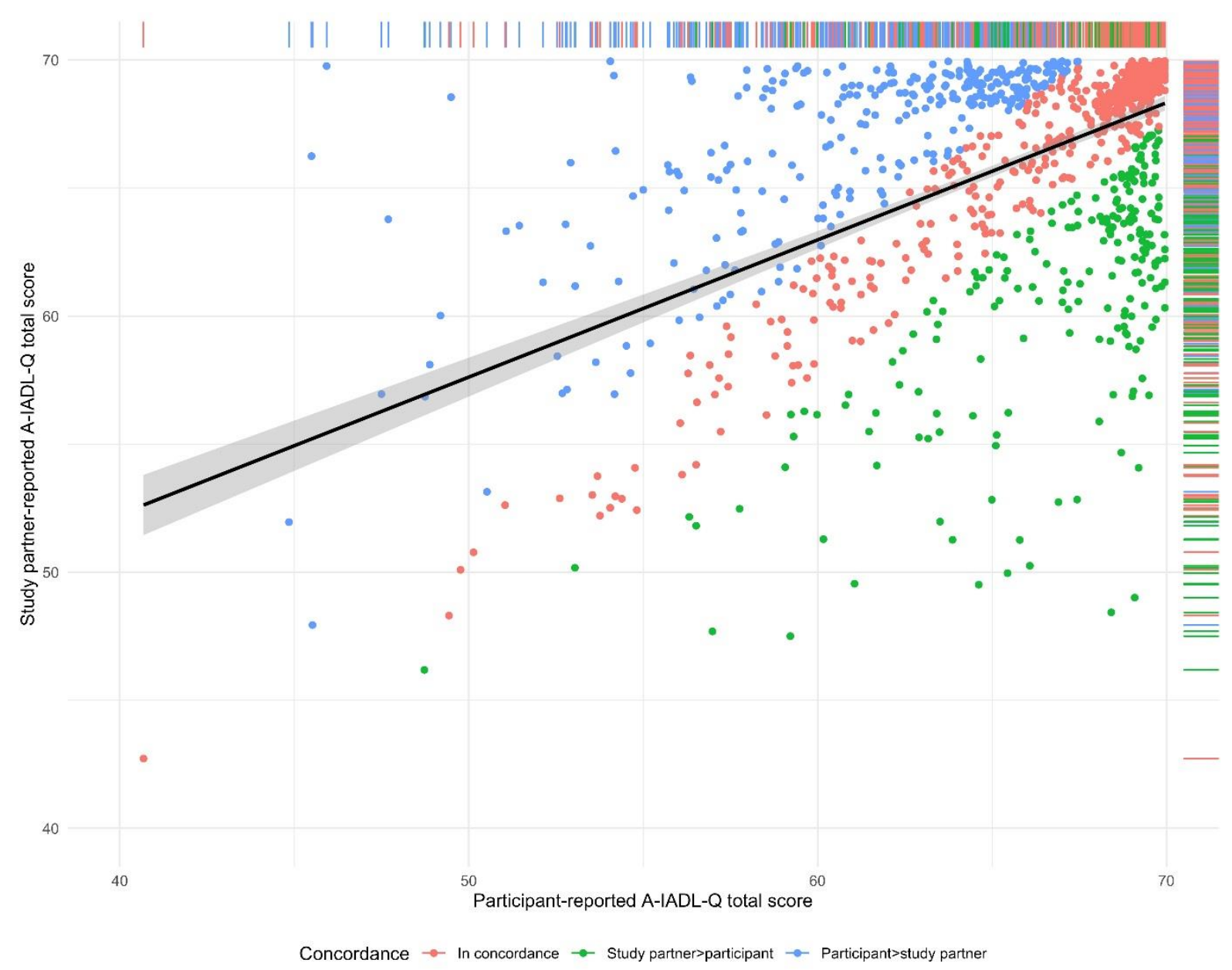

Figure 1. Scatterplot showing the relationship (black line) between participant-reported (horizontal axis) and study partner-reported IADL functioning (vertical axis).

Each dot represents an individual; dots are colored based on a difference in IADL-Q scores of 2.4 points or more: dyads in concordance are red, dyads where the study partner reported better A-IADL-Q scores than the participant are green, dyads where the participant reported better A-IADL-Q scores than the study partner are blue. 